\title{
Basel III in India: Where are we heading?
}

\author{
Swapna Samanta*
}

\begin{abstract}
Basel norms are designed to ensure safety and stability of the banking system at an international level. The norms were introduced in 1988, known in the name of Basel I, which through subsequent and continuous modifications has now taken the shape of Basel III in 2010-2011.Indian banks being internationally active, are well preparing themselves to comply with the norms. The paper tries to revisit the Basel III requirements and analyses the preparedness of the Indian banks for meeting the same. It makes an attempt to critically understand the contribution of these norms towards economic growth of the country.
\end{abstract}

Keywords: Basel III, Capital Adequacy, Credit, Liquidity.

\subsection{Introduction}

Basel III is a part of the continuous effort made by the Basel Committee on Banking Supervision to enhance the banking regulatory framework. It builds on the Basel I and Basel II documents, and seeks to improve the banking sector's ability to deal with financial and economic stress, improve risk management and strengthen the banks' transparency. A focus of Basel III is to foster greater resilience at the individual bank level in order to reduce the risk of system wide shocks.

Basel III has been devised as a response to the financial crisis that hit most of the economies from 2007 onwards. The Basel committee's primary objective is strengthening of the bank's capital. This is defined in terms of the Capital Adequacy Ratio, i.e., Capital to Risk weighted Assets Ratio (CAR or CRAR). Basel I introduced the concept of capital adequacy. Basel II mainly stressed upon the denominator, i.e., risk weighted assets, and gave various measures to optimally assess the level of risk that the bank is exposed to. Once Basel II failed to address the problem, the Basel committee members shifted their attention to the numerator of the CRAR, i.e., the capital.

*Research Scholar, Department of Commerce, University of Calcutta.

Acknowledgement: The author would like to express gratitude to her supervisor, Dr. Tanupa Chakraborty, for her guidance and support. 
The objective of this study is to find out the preparedness of Indian banks to live up to the requirements of Basel III. Even if it is established that Indian banks are prepared, the question remains, about the effectiveness of the Basel III norms towards enhancement of the banking sector and development of Indian economy as a whole.

The paper is organised in seven sections: the first section introduces the topic, the second provides a review of studies on the Basel norms, the third deals with the background of the Basel Committee, the fourth gives a brief history of the Indian banking sector and its association with Basel norms, the fifth tells about the requirements of the Basel III, the sixth tests the preparedness of Indian banks to accept those changes and the seventh draws the conclusion of this study.

\subsection{Literature Review}

This section discusses some significant studies on Basel norms both in India and abroad. The Banking Association, South Africa (2005) has published a paper to provide a basic insight into the Basel II document for individuals, for example, a new financial market analysts and financial journalist needing a basic understanding or introduction to the current bank supervision and regulation. Bailey (2005) states that Basel II represents something of a "Catch 22" for developing countries as Basel compliance would mean local banks becoming vulnerable to acquisition by their international counterparts while non-compliance will avoid this, but exclude local banks from overseas markets. Balin (2008) discusses the Basel accords in simple language and brings out the disharmony of the Accords once applied in the emerging market economies. Balthazar (2006) gives a practical overview of the Basel Accords and also outlines the challenges that would have to be met to reach the new regulatory standards. Agarwal and Sirohy (2010) showcase the changes that will emerge as a result of Indian banks adopting the international norms. They are of the opinion that scientific risk management will change the face of banking in India. Small banks will not be able to sustain the pressure and will eventually disappear. Large banks will be able to control the defaults with efficient credit scoring techniques. Good credit customers would be given high scores. These scores would be monitored through a centralised system and the same score could be used for various products of the same bank. Eventually, new products would be developed for good credit customers in the profitable segment. The economy will stand to benefit as the banking sector develops. Savings will be mobilised in the right direction and the required funds needed for the country's development will be made available.

The present study revisits the Basel III norms and tries to anticipate the destiny of the Indian Banking system under Basel III regime. 


\subsection{The Background and Formation of the Basel Committee}

The Basel Committee on Banking Supervision (or Basel Committee for short) plays a leading role in standardising bank regulations across jurisdictions. Its origins can be traced to June 26, 1974, when German regulators forced the troubled Bank Herstatt into liquidation. That day, a number of banks had released payment of German marks to Herstatt in Frankfurt in exchange for US dollars that was to be delivered in New York. Due to time-zone differences, Herstatt ceased operations between the times of the respective payments. The counterparty banks did not receive their dollar payments.

Responding to the cross-jurisdictional implications of the Herstatt debacle, G-10 countries and Luxembourg formed a standing committee under the auspices of the Bank for International Settlements (BIS). Called the Basel Committee on Banking Supervision, the Committee comprised representatives from participant nations' Central banks and regulatory authorities. Over time, the focus of the Committee has evolved, embracing initiatives designed to define roles of regulators in cross-jurisdictional situations; ensure that international banks or bank holding companies do not escape comprehensive supervision by a "home" regulatory authority; promote uniform capital requirements so that banks from different countries may compete with one another on a "level playing field."

The Basel Committee does not have legislative authority, but participant countries are expected to implement its recommendations. Also, the Committee sometimes allows for flexibility in how local authorities implement recommendations. In recent decades, the Basel Committee has focused on developing a uniform system of bank capital requirements, called the Basel Accords. Work commenced with a 1988 Basel Accord, which is today called Basel I. That set minimum capital requirements of $8 \%$ as the minimum capital adequacy ratio for banks' credit risk. It was the first ever attempt at harmonising the banks' capital standards across the countries, for securing greater international competitive equality and to obviate regulatory capital as a source of competitive inequality. The Accord, in its original form, addressed only the credit risks in the banks' operations. A 1996 amendment added capital charges for market risk. With time it was felt that Basel I suffered from some serious limitations. The capital requirements were risk insensitive and only depended on three broad categories: sovereign, banks and corporates, with each category attracting a risk weight of zero, 20 and 100 per cent, respectively. The operational risk, that is, the risk of human error or failure of systems leading to financial loss, was not at all addressed - as were the liquidity risk, credit concentration risk, interest rate risk in the banking book, etc. Also 
off balance sheet exposures, that started gaining significance due to the emergence of innovative financial products and involved considerable amount of risk, was not considered under Basel I. Starting in 1999 and continuing into the early 2000s, the Basel Committee developed an improvement of Basel 1, which was called Basel II initiated in 2004. One of the unique aspects of Basel II is its comprehensive approach to risk measurement in the banking entities, by adopting a three-Pillar structure, which goes far beyond the first Basel Accord. The three pillars are: Pillar 1 - the minimum capital ratio, Pillar 2 - the supervisory review process and Pillar 3 - the market discipline. The Pillar 1 provides a menu of alternative approaches, from simple to advanced ones, for determining the regulatory capital towards credit risk, market risk and operational risk, to cater to the wide diversity in the banking system across the world. Pillar 2 requires the banks to establish an Internal Capital Adequacy Assessment Process (ICAAP) to capture all the material risks, including those that are partly covered or not covered under the other two Pillars. The ICAAP of the banks is also required to be subject to a supervisory review by the supervisors. Pillar 3 prescribes public disclosures of information on the affairs of the banks to enable effective market discipline on the banks' operations. Implementation of Basel II was nearing completion when the 2008 financial crisis hit. With governments bailing out numerous financial institutions, it was clear the Basel Accords were still inadequate. The Basel Committee responded with a number of stopgap measures, which have been called Basel 2.5, followed by a longerterm overhaul of bank capital requirements in 2010-11, which is called Basel III.

\subsection{The Evolution of the Indian Banking System}

Since 1991, India has engaged in banking sector reforms aimed at increasing the profitability and efficiency of the then 27 public-sector banks that controlled about 90 per cent of all deposits, assets and credit. Prior to the reforms, India's financial sector had long been characterised as highly regulated and financially repressed. The prevalence of reserve requirements, interest rate controls, and allocation of financial resources to priority sectors increased the degree of financial repression and adversely affected the country's financial resource mobilisation and allocation.

The government attempted to close the Indian economy to the outside world. The Indian currency, the rupee, was non-convertible and high tariffs and import licensing prevented foreign goods from reaching the market. India also operated a system of central planning for the economy, in which firms required licences to invest and develop. This bureaucracy often led to absurd restrictions - up to 80 agencies had to be satisfied before a firm could be granted a licence to produce and the State would decide what was 
produced, how much, at what price and what sources of capital were used. The government also prevented firms from laying off workers or closing factories. The central pillar of the policy was import substitution, the belief that India needed to rely on internal markets for development, not international trade - a belief generated by a mixture of socialism and the experience of colonial exploitation. Planning of the State, rather than markets, would determine how much investment was needed in which sectors.

It is evident from this economic scenario, that the banks were characterised by massive under-lending. Procuring loans by entrepreneurs was almost impossible. Banks' funds were mostly channelised towards investment, primarily in Government securities. A smaller fraction went towards credit to the weakly developed industrial sector. There also the privilege went towards the priority sector where recovery of the lent fund was mostly not assured. Thus a system emerged with high degree of regulation, repression and lack of any free market mechanism. International transactions were very limited. The concept of risk comes from uncertainty. The absence of free fund flow or market determined financial instruments did not give birth to uncertainty as such. Naturally, under such a situation, risk management and Basel norms were absolutely without any relevance in India.

Deregulation of interest rates has been one of the key features of Indian financial sector reforms initiated since 1991. Only after 1994, some freedom was granted to banks in term of fixing their trading limits, borrowing and investing funds in the overseas markets up to specified limits, making use of derivative products for asset-liability management purposes. In recent years, the reform agenda has improved the competitiveness of Indian financial environment and strengthened the transmission mechanism of its monetary policy. Sequencing of interest rate deregulation has also enabled better price discovery of fund and imparted greater efficiency to the resource allocation process. Furthermore, banks have been allowed to diversify product portfolio and business activities. The share of public sector banks in the banking business has gone down, particularly in metropolitan areas. Some diversification of ownership in select public sector banks has helped further the move towards their autonomy and thus provided some response to competitive pressures. Transparency and disclosure standards have been enhanced to meet international standards in an ongoing manner. Also under competitive pressure, and in search of higher return, Indian banks are hugely diversifying their asset portfolio, coming up with newer and riskier financial products, and assuming more and more risks thereby increasing the significance of effective risk management. 
Despite all reforms, Indian banks are characterised by their risk averse nature and substantial under lending and financial repression. One instance is the mechanism of the "statutory liquidity ratio" (SLR). Indian banks must hold 23\% of their assets in the form of government bonds. This is far higher than they would naturally choose to do. It means that the banks must pay lower rates to their depositors than they would be able to do if they could invest in higher return assets and it distorts the financial system's ability to fund the private sector. The official reasons for the policy are to restrict the growth of credit to the private sector and to ensure the financial strength of the banks. However, both of these goals can be achieved by other means and the real reason is to make it easier to fund the government's deficit, meaning that interest rates are lower than they would otherwise be. In effect, by cutting the government's interest payments, this policy reduces the need for taxation.

Keeping in view the goal to achieve consistency and harmony with international standards, it was decided by India's central bank, the Reserve Bank of India (RBI), to adopt Basel I since April 1992 in a phased manner spread over 3 years: banks with branches abroad were required to comply fully by end March 1994 and the other banks were required to comply by end March 1996. Further, India responded to the 1996 amendment to the Basel I framework which required banks to maintain capital for market risk exposures, by initially prescribing various surrogate capital charges for these risks between 2000 and 2002. These were replaced with the capital charges as required under the Basel I framework in June 2004, which become fully effective from March 2005.

With the passage of time, it was realised that the Basel I framework had several limitations. The limitations related mainly to the underlying approach as also a less-thancomprehensive scope of the Accord in capturing the entire risk universe of the banking entities. A need was felt to create a more comprehensive and risk-sensitive capital adequacy framework to address the infirmities in the Basel I Accord. The Basel Committee on Banking Supervision (BCBS), therefore, started a world-wide consultative process and India's contribution in this regard dates back to 1997 as India was among the 16 non-member countries that were consulted in the drafting of the Basel Core Principles. Reserve Bank of India became a member of the Core Principles Liaison Group in 1998 and subsequently became a member of the Core Principles Working Group on Capital. RBI has been actively participating in the deliberations on the Accord and had the privilege to lead a group of 6 major non $\mathrm{G}-10$ supervisors which presented a proposal on a simplified approach for Basel II to the Committee.

After several impact assessment studies, evolved a new capital regulation framework, called "International Convergence of Capital Measurement and Capital Standards: A 
Revised Framework", which was released in June 2004. The revised framework has come to be commonly known as "Basel II" framework and seeks to foster better risk management practices in the banking industry.

RBI issued the guidelines for the new capital adequacy framework in regard to Pillar 1 and Pillar 3 on April 27, 2007. As regards Pillar 2, the banks have been advised to put in place an Internal Capital Adequacy Assessment Process (ICAAP), with the approval of the Board. A two-stage implementation of the guidelines is envisaged to provide adequate lead time to the banking system. Accordingly, the foreign banks operating in India and the Indian banks having operational presence outside India are required to migrate to the Standardised Approach for credit risk and the Basic Indicator Approach for operational risk with effect from March 31, 2008. All other Scheduled commercial banks are encouraged to migrate to these approaches under Basel II in alignment with them, but, in any case, not later than March 31, 2009. It has been a conscious decision to begin with the simpler approaches available under the framework, having regard to the preparedness of the banking system. As regards the market risk, under Basel II also, the banks will continue to follow the Standardised-Duration Method as already adopted under the Basel I framework. For migration to the advanced approaches available under the framework, prior approval of the RBI would be required. In this backdrop of risk management in the light of Basel norms, Basel III was introduced.

\subsection{Key features of Basel III}

\subsection{Better capital quality}

One of the key elements of Basel III is the introduction of much stricter definition of capital. Better quality capital means the higher loss-absorbing capacity. This in turn will mean that banks will be stronger, allowing them to better withstand periods of stress.

\subsection{Capital conservation buffer}

Another key feature of Basel III is that now banks will be required to hold a capital conservation buffer of $2.5 \%$. The aim of asking to build conservation buffer is to ensure that banks maintain a cushion of capital that can be used to absorb losses during periods of financial and economic stress.

\subsection{Countercyclical buffer}


The countercyclical buffer has been introduced with the objective to increase capital requirements in good times and decrease the same in bad times. The buffer will slow banking activity when it overheats and will encourage lending when times are tough i.e. in bad times. The buffer will range from $0 \%$ to $2.5 \%$, consisting of common equity or other fully loss-absorbing capital.

\subsection{Minimum common equity and Tier 1 capital requirements}

The minimum requirement for common equity, the highest form of lossabsorbing capital, has been raised under Basel III from $2 \%$ to $4.5 \%$ of total risk-weighted assets. The overall Tier 1 capital requirement, consisting of not only common equity but also other qualifying financial instruments, will also increase from the current minimum of $4 \%$ to $6 \%$. Although the minimum total capital requirement will remain at the current $8 \%$ level, yet the required total capital will increase to $10.5 \%$ when combined with the conservation buffer.

\subsection{Leverage ratio}

A review of the financial crisis of 2008 has indicted that the value of many assets fell quicker than assumed from historical experience. Thus, now Basel III rules include a leverage ratio to serve as a safety net. A leverage ratio is the relative amount of capital to total assets (not risk-weighted). This aims to put a cap on swelling of leverage in the banking sector on a global basis. 3\% leverage ratio of Tier 1 will be tested before a mandatory leverage ratio is introduced in January 2018.

\subsection{Liquidity Ratios}

Under Basel III, a framework for liquidity risk management will be created. Two new liquidity ratios, Liquidity Coverage Ratio (LCR) and Net Stable Funding Ratio (NSFR) are to be introduced in 2015 and 2018, respectively.

\subsection{Systemically Important Financial Institutions (SIFI)}

As part of the macro-prudential framework, systemically important banks will be expected to have loss-absorbing capability beyond the Basel III requirements. Options for implementation include capital surcharges, contingent capital and bail-in-debt.

Table 1 and Table 2 give a comparison of capital requirements and liquidity standards under Basel II and Basel III respectively. 
Table 1: Capital Requirements under Basel II and Basel III

\begin{tabular}{|c|c|c|c|}
\hline \multirow{2}{*}{} & & Basel II & $\begin{array}{c}\text { Basel III (as on } \\
\text { January 1, 2019) }\end{array}$ \\
\hline $\mathrm{A}=(\mathrm{B}+\mathrm{D})$ & Minimum Total Capital & 8.0 & 8.0 \\
\hline $\mathrm{B}$ & Minimum Tier 1 Capital & 4.0 & 6.0 \\
\hline $\mathrm{C}$ & $\begin{array}{c}\text { of which: } \\
\text { Jinimum Common Equity Tier 1 Capital }\end{array}$ & 2.0 & 4.5 \\
\hline $\mathrm{D}$ & Maximum Tier 2 Capital (within Total \\
Capital) & 4.0 & 2.0 \\
\hline $\mathrm{E}$ & Capital Conservation Buffer (CCB) & - & 2.5 \\
\hline $\mathrm{F}=\mathrm{C}+\mathrm{E}$ & Minimum Common Equity Tier 1 Capital \\
& $\begin{array}{c}\text { + CCB } \\
\mathrm{G}=\mathrm{A}+\mathrm{E}\end{array}$ & 2.0 & 7.0 \\
\hline
\end{tabular}

Source: RBI, "Basel III in International and Indian Contexts Ten Questions We Should Know the Answers For", Inaugural Address by Dr. Duvvuri Subbarao, Governor, Reserve Bank of India at the Annual FICCI IBA Banking Conference at Mumbai on September 04, 2012.

Table 2: Liquidity Standards under Basel II and Basel III

\begin{tabular}{|c|c|l|}
\hline Ratio & Basel II & \multicolumn{1}{c|}{ Basel III } \\
\hline $\begin{array}{c}\text { Liquidity Coverage } \\
\text { Ratio (LCR) } \\
\text { (to be introduced as on } \\
\text { January 1, 2015) }\end{array}$ & - & $\begin{array}{l}\text { Stock of high-quality liquid assets } \geq 100 \% \\
\text { Total net cash outflows over the } \\
\text { next 30 calendar days }\end{array}$ \\
\hline $\begin{array}{c}\text { Net Stable Funding } \\
\text { Ratio (NSFR) } \\
\text { (to be introduced as on } \\
\text { January 1, 2018) }\end{array}$ & - & $\begin{array}{l}\text { Available amount of stable funding }>100 \% \\
\text { Required amount of stable funding }\end{array}$ \\
\hline
\end{tabular}

Source: RBI, "Basel III in International and Indian Contexts Ten Questions We Should Know the Answers For", Inaugural Address by Dr. Duvvuri Subbarao, Governor, Reserve Bank of India at the Annual FICCI IBA Banking Conference at Mumbai on September 04, 2012.

\subsection{India's preparation for Basel III}

We now look into the potential impact that Basel III can have on Indian banking system as the norms have already kick-started in a phased manner from January 1, 2013. Reserve Bank of India has prescribed higher capital and leverage norms for Indian banks than the Basel III minimum. Table 3 summarises the Basel III (international) 
92 MUDRA: Journal of Finance and Accounting, Vol. 2, Issue 1

prescriptions alongside the current requirements in India under Basel II, and as required under Basel III when fully implemented.

Table 3: Minimum Regulatory Capital Prescriptions (as percentage of risk weighted assets)

\begin{tabular}{|c|c|c|c|c|}
\hline & & $\begin{array}{c}\text { Basel III } \\
\text { (as on January }\end{array}$ & \multicolumn{2}{|c|}{$\begin{array}{l}\text { Reserve Bank's } \\
\text { Prescriptions }\end{array}$} \\
\hline & & & $\begin{array}{l}\text { Current } \\
\text { (Basel II) }\end{array}$ & $\begin{array}{c}\text { Basel III } \\
\text { (as on March 31, } \\
\text { 2018) }\end{array}$ \\
\hline $\begin{array}{c}\mathrm{A}= \\
(\mathrm{B}+\mathrm{D})\end{array}$ & Minimum Total Capital & 8.0 & 9.0 & 9.0 \\
\hline $\mathrm{B}$ & Minimum Tier 1 capital & 6.0 & 6.0 & 7.0 \\
\hline $\mathrm{C}$ & $\begin{array}{c}\text { of which: } \\
\text { Minimum Common Equity } \\
\text { Tier } 1 \text { capital }\end{array}$ & 4.5 & 3.6 & 5.5 \\
\hline $\mathrm{D}$ & $\begin{array}{l}\text { Maximum Tier } 2 \text { capital } \\
\text { (within Total Capital) }\end{array}$ & 2.0 & 3.0 & 2.0 \\
\hline $\mathrm{E}$ & $\begin{array}{l}\text { Capital Conservation Buffer } \\
\text { (CCB) }\end{array}$ & 2.5 & - & 2.5 \\
\hline $\begin{array}{l}\mathrm{F}= \\
\mathrm{C}+\mathrm{E}\end{array}$ & $\begin{array}{l}\text { Minimum Common Equity } \\
\text { Tier } 1 \text { capital + CCB }\end{array}$ & 7.0 & 3.6 & 8.0 \\
\hline $\begin{array}{c}G= \\
A+E\end{array}$ & $\begin{array}{l}\text { Minimum Total Capital + } \\
\text { CCB }\end{array}$ & 10.5 & - & 11.5 \\
\hline $\mathrm{H}$ & $\begin{array}{l}\text { Leverage Ratio (ratio to total } \\
\text { assets) }\end{array}$ & 3.0 & - & 4.5 \\
\hline
\end{tabular}

Source: RBI, "Basel III in International and Indian Contexts Ten Questions We Should Know the Answers For", Inaugural Address by Dr. Duvvuri Subbarao, Governor, Reserve Bank of India at the Annual FICCI IBA Banking Conference at Mumbai on September 04, 2012.

\subsection{Capital adequacy}

RBI's 2012 estimates projected an additional capital requirement of Rs. 5 trillion, of which non-equity capital would be of the order of Rs.3.25 trillion while equity capital would be of the order of Rs.1.75 trillion (Table 4). For Indian banks, its easier to make the transition to a stricter capital requirement regime than some of their international counterparts since the regulatory norms set by RBI on capital adequacy are 
already more stringent. Besides, most Indian banks have historically maintained their core and overall capital well in excess of the regulatory minimum.

\section{Table 4: Additional Common Equity Requirements of Indian Banks under Basel III}

(Rs. billion)

\begin{tabular}{|c|c|c|c|c|}
\hline & & $\begin{array}{l}\text { Public Sector } \\
\text { Banks }\end{array}$ & $\begin{array}{c}\text { Private Sector } \\
\text { Banks }\end{array}$ & Total \\
\hline A & $\begin{array}{c}\text { Additional Equity Capital Requirements } \\
\text { under Basel III }\end{array}$ & $1400-1500$ & $200-250$ & $\begin{array}{r}1600- \\
1750\end{array}$ \\
\hline B & $\begin{array}{c}\text { Additional Equity Capital Requirements } \\
\text { under Basel II }\end{array}$ & $650-700$ & $20-25$ & $\begin{array}{r}670- \\
725\end{array}$ \\
\hline $\mathrm{C}$ & $\begin{array}{l}\text { Net Equity Capital Requirements under } \\
\text { Basel III (A-B) }\end{array}$ & $750-800$ & $180-225$ & $\begin{array}{l}930- \\
1025\end{array}$ \\
\hline D & $\begin{array}{c}\text { Of Additional Equity Capital } \\
\text { Requirements under Basel III for Public } \\
\text { Sector Banks (A) }\end{array}$ & & & \\
\hline & $\begin{array}{c}\text { Government Share (if present } \\
\text { shareholding pattern is maintained) }\end{array}$ & $880-910$ & - & - \\
\hline & $\begin{array}{c}\text { Government Share (if shareholding is } \\
\text { brought down to } 51 \text { per cent) }\end{array}$ & $660-690$ & - & - \\
\hline & $\begin{array}{l}\text { Market Share (if the Government's } \\
\text { shareholding pattern is maintained at } \\
\text { present level) }\end{array}$ & $520-590$ & - & - \\
\hline
\end{tabular}

Source: RBI, "Basel III in International and Indian Contexts Ten Questions We Should Know the Answers For", Inaugural Address by Dr. Duvvuri Subbarao, Governor, Reserve Bank of India at the Annual FICCI IBA Banking Conference at Mumbai on September 04, 2012.

According to a CRISIL estimate, the average equity capital ratio and overall capital adequacy ratio of rated banks in India stands well above 9\% and 14\%, respectively. The capital adequacy ratio of Indian Banks as per Basel III requirements as on March, 2014 are given in Table 5 below.

\subsection{Cost of lending}

Stricter capital requirements with changes in the structure of tier 1 and tier 2 capitals in Basel III require higher and better quality capital. Admittedly, the cost of equity capital is high. It is also likely that the loss absorbency requirements on the nonequity regulatory capital will increase its cost. The average Return on Equity (RoE) of 
94 | MUDRA: Journal of Finance and Accounting, Vol. 2, Issue 1

the Indian banking system for the last three years has been approximately 15 per cent. Implementation of Basel III is expected to result in a decline in Indian banks' RoE. As capital costs increase, loans tend to be expensive. In order to offset this, banks would have to take the route of reducing deposit interest and go in for new non-interest income streams.

Table 5: CAR of Indian Banks as per Basel III requirements as on March, 2014

\begin{tabular}{|c|c|}
\hline BANK & CAR (\%) \\
\hline \multicolumn{2}{|c|}{ Public Sector Banks } \\
\hline Allahabad Bank & 9.96 \\
\hline Andhra Bank & 10.78 \\
\hline Bank of Baroda & 12.28 \\
\hline Bank of India & 9.97 \\
\hline Bank of Maharashtra & 10.79 \\
\hline Canara Bank & 10.63 \\
\hline Central Bank of India & 9.87 \\
\hline Corporation Bank & 11.64 \\
\hline Dena Bank & 11.14 \\
\hline Indian Bank & 12.64 \\
\hline Indian Overseas Bank & 10.78 \\
\hline Oriental Bank of Commerce & 11.01 \\
\hline Punjab \& Sind Bank & 11.04 \\
\hline Punjab National Bank & 11.52 \\
\hline Syndicate Bank & 11.41 \\
\hline UCO Bank & 12.68 \\
\hline Union Bank of India & 10.80 \\
\hline United Bank of India & 9.81 \\
\hline Vijaya Bank & 10.56 \\
\hline State Bank of India (SBI) & 12.44 \\
\hline State Bank of Bikaner \& Jaipur & 11.55 \\
\hline State Bank of Hyderabad & 12.00 \\
\hline State Bank of Mysore & 11.08 \\
\hline
\end{tabular}




\begin{tabular}{|l|l|}
\hline State Bank of Patiala & 10.38 \\
\hline State Bank of Travancore & 10.79 \\
\hline IDBI Ltd. & 11.68 \\
\hline \multicolumn{2}{|c|}{ Private Sector Banks } \\
\hline City Union Bank Ltd. & 15.01 \\
\hline ING Vysya Bank Ltd. & 14.63 \\
\hline Tamilnad Mercantile Bank Ltd. & 15.59 \\
\hline The Catholic Syrian Bank Ltd. & 11.00 \\
\hline Dhanlaxmi Bank Ltd & 8.67 \\
\hline The Federal Bank Ltd. & 15.14 \\
\hline The Jammu \& Kashmir Bank Ltd. & 12.69 \\
\hline The Karnataka Bank Ltd. & 13.20 \\
\hline The KarurVysya Bank Ltd. & 12.60 \\
\hline The Lakshmi Vilas Bank Ltd. & 10.90 \\
\hline Nainital Bank Ltd. & 15.13 \\
\hline RBL Bank & 14.64 \\
\hline The South Indian Bank Ltd. & 12.42 \\
\hline Axis Bank Ltd. & 16.07 \\
\hline Development Credit Bank Ltd. & 13.71 \\
\hline HDFC Bank Ltd. & 16.07 \\
\hline ICICI Bank Ltd. & 17.70 \\
\hline Indusind Bank Ltd. & 13.83 \\
\hline Kotak Mahindra Bank Ltd. & 18.83 \\
\hline YES Bank & 14.40 \\
\hline & \\
\hline AB Bank Limited & 29.10 \\
\hline Abu Dhabi Commercial Bank Limited & 35.92 \\
\hline American Express Banking Corporation & 16.56 \\
\hline Antwerp Diamond Bank N.V. & 34.19 \\
\hline Australia \& New Zealand Banking Group Limited & 30.82 \\
\hline Bank Internasional Indonesia & 217.97 \\
\hline Bank of America NA & 16.70 \\
\hline Bank of Bahrain and Kuwait B.S.C. & 33.57 \\
\hline Bank of Ceylon & \\
\hline & \\
\hline
\end{tabular}


96 | MUDRA: Journal of Finance and Accounting, Vol. 2, Issue 1

\begin{tabular}{|c|c|}
\hline Barclays Bank PLC & 19.72 \\
\hline BNP Paribas & 13.89 \\
\hline CTBC Bank Co.,Ltd. & 45.55 \\
\hline Citibank N.A. & 14.38 \\
\hline Commonwealth Bank of Australia & 35.59 \\
\hline Credit Agricole Corporate \& Investment Bank & 16.05 \\
\hline Credit Suisse AG & 19.93 \\
\hline DBS Bank Ltd. & 13.81 \\
\hline Deutsche Bank AG & 14.84 \\
\hline FirstRand Bank Ltd. & 40.53 \\
\hline HSBC Bank Oman S.A.O.G. & 56.93 \\
\hline Industrial \& Commercial Bank of China Limited & 47.87 \\
\hline JPMorgan Chase Bank & 25.58 \\
\hline JSC VTB Bank & 34.71 \\
\hline Krung Thai Bank Public Company Ltd. & 50.52 \\
\hline Mashreqbankpsc & 34.17 \\
\hline Mizuho Bank Ltd. & 48.11 \\
\hline National Australia Bank Ltd. & 201.85 \\
\hline Rabobank International & 39.04 \\
\hline Sberbank & 51.92 \\
\hline Shinhan Bank & 46.24 \\
\hline SocieteGenerale & 30.26 \\
\hline Sonali Bank Ltd. & 12.12 \\
\hline Standard Chartered Bank & 12.48 \\
\hline State Bank of Mauritius Ltd. & 39.47 \\
\hline Sumitomo Mitsui Banking Corporation & 80.12 \\
\hline The Bank of Nova Scotia & 19.59 \\
\hline The Bank of Tokyo-Mitsubishi UFJ, Ltd. & 39.15 \\
\hline The Hongkong and Shanghai Banking Corpn.Ltd. & 17.36 \\
\hline The Royal Bank of Scotland & 15.31 \\
\hline UBS AG & 247.28 \\
\hline United Overseas Bank Ltd. & 89.51 \\
\hline Westpac Banking Corporation & 43.61 \\
\hline Woori Bank & 141.52 \\
\hline
\end{tabular}

Source: IBA (Key Business Statistics) 


\subsection{Leverage}

RBI has set the leverage ratio at $4.5 \%$ ( $3 \%$ under Basel III).The ratio is introduced by Basel III to regulate banks having huge trading book and off balance sheet derivative positions. In India, however, in most of our banks, the derivative activities are not very large so as to arrange enhanced cover for counterparty credit risk. Hence, the pressure on banks should be moderate.

\subsection{Liquidity norms}

Indian banks conform to two liquidity buffers already: the statutory liquidity ratio (SLR) - a mandatory $24 \%$ of a bank's net demand and time liabilities - and cash reserve ratio (CRR) of $4.75 \%$. The SLR is mainly government securities while the CRR is mainly cash. The Liquidity Coverage Ratio (LCR) under Basel III requires banks to hold enough unencumbered liquid assets to cover expected net outflows during a 30-day stress period. In India, the burden from LCR stipulation will depend on how much of CRR and SLR can be offset against LCR. Here too, Indian banks are better placed over their overseas counterparts.

\subsection{Countercyclical buffer}

Economic activity moves in cycles and banking system is inherently pro-cyclic. During upswings, carried away by the boom, banks end up in excessive lending and unchecked risk build-up, which carry the seeds of a disastrous downturn. The regulation to create additional capital buffers to lend further would act as a break on unbridled bank-lending. This check will counter or smoothen wild swings in business cycles. India has witnessed moderate cycles. Yet, for countercyclical measures to be effective, our banking system has to improve its capability to sense and predict the business cycle at sectoral and systemic levels and to use tools like 'Credit to GDP ratio' to calibrate the level of countercyclical buffer.

\subsection{Conclusion}

Under the given situation, factors like the quality of governance of banks, the standard of regulatory control by RBI and the level of public confidence banks enjoy in combination with their adherence to Basel III standards will earn a prestigious position of Indian banking system on the world scene. From the perspective of risk management and compliance to Basel III, the position of Indian Banks is stable. But the question remains, how desirable is this soundness and stability? In the process of compliance to Basel III and its overprotective norms, are we not walking backwards in the path of 
historical regulation and financial repression from which after very bitter lessons, our economy had managed to gain some freedom. The risk aversion and under lending will again lead to retarded industrial growth which will leave a deep dent on our economy. The higher capital requirements under Basel III will definitely pose to be an impediment against the increasing credit demand (Table 6) of India's structurally transforming economy with rapid upward mobility.

Table 6: Increasing Predominance of Credit over Investments

\begin{tabular}{|c|c|c|c|}
\hline Year & $\begin{array}{c}\text { Credit of Scheduled } \\
\text { Commercial Banks in } \\
\text { India (Rs. crore) }\end{array}$ & $\begin{array}{c}\text { Investments of } \\
\text { Scheduled } \\
\text { Commercial Banks } \\
\text { in India (Rs. crore) }\end{array}$ & $\begin{array}{c}\text { Credit / } \\
\text { (Credit+Investment) } \\
\text { (\%) }\end{array}$ \\
\hline Mar-01 & 529271 & 367184 & 59.04 \\
\hline Mar-02 & 609053 & 437482 & 58.20 \\
\hline Mar-03 & 746432 & 547546 & 57.69 \\
\hline Mar-04 & 840785 & 677588 & 55.37 \\
\hline Mar-05 & 1100428 & 739154 & 59.82 \\
\hline Mar-06 & 1507077 & 717454 & 67.75 \\
\hline Mar-07 & 1931190 & 791516 & 70.93 \\
\hline Mar-08 & 2361913 & 971714 & 70.85 \\
\hline Mar-09 & 2775549 & 1166410 & 70.41 \\
\hline Mar-10 & 3244788 & 1384753 & 70.09 \\
\hline Mar-11 & 3942083 & 1501619 & 72.42 \\
\hline Mar-12 & 4611852 & 1737787 & 72.63 \\
\hline Mar-13 & 5260459 & 2006105 & 72.39 \\
\hline Mar-14 & 6735232 & 2882853 & 70.03 \\
\hline
\end{tabular}

Source: RBI (Statistical Tables Relating to Banks in India)

India will shift increasingly from services to manufacturing, and the credit intensity of manufacturing is higher per unit of GDP than that for services. Second, we need to at least double our investment in infrastructure which will place enormous demands on credit. Finally, financial inclusion, which both the Government and the Reserve Bank are driving, will bring millions of low income households into the formal financial system with almost all of them needing credit. Thus Basel III might raise the cost of credit and hence mitigate growth. 


\section{References}

Agarwal, A. \& Sirohy, S. (2010). Future of risk management in Indian banking industry. Working Paper, IIM Lucknow, July.

Bailey, R. (2005). Basel II and developing countries: Understanding the implications. Working Paper Series, No. - 05-71, Development Studies Institute, London School of Economics and Political Science, December, available at www2.lse.ac.uk.

Balin B. J. (2008). Basel I, Basel II, and Emerging Markets: A Nontechnical Analysis. Working Paper, The Johns Hopkins University School of Advanced International Studies (SAIS), Washington DC, USA.

Balthazar, L. (2006). From Basel 1 to Basel 3: The integration of state-of-the-art risk modeling in banking regulation. Palgrave Macmillan.

The Banking Association, South Africa. (2005). The Banker's Guide to the Basel II Framework", Research Paper, December, available on the internet at www.scribd.com.

\section{Weblinks}

www.allbankingsolutions.com

www.bis.org

www.dnaindia.com

www.iba.org.in

www.rbi.org.in. 